\title{
Diversity of cultivable bacteria from deep-Sea sediments of the Colombian Caribbean and their Potential in Bioremediation
}

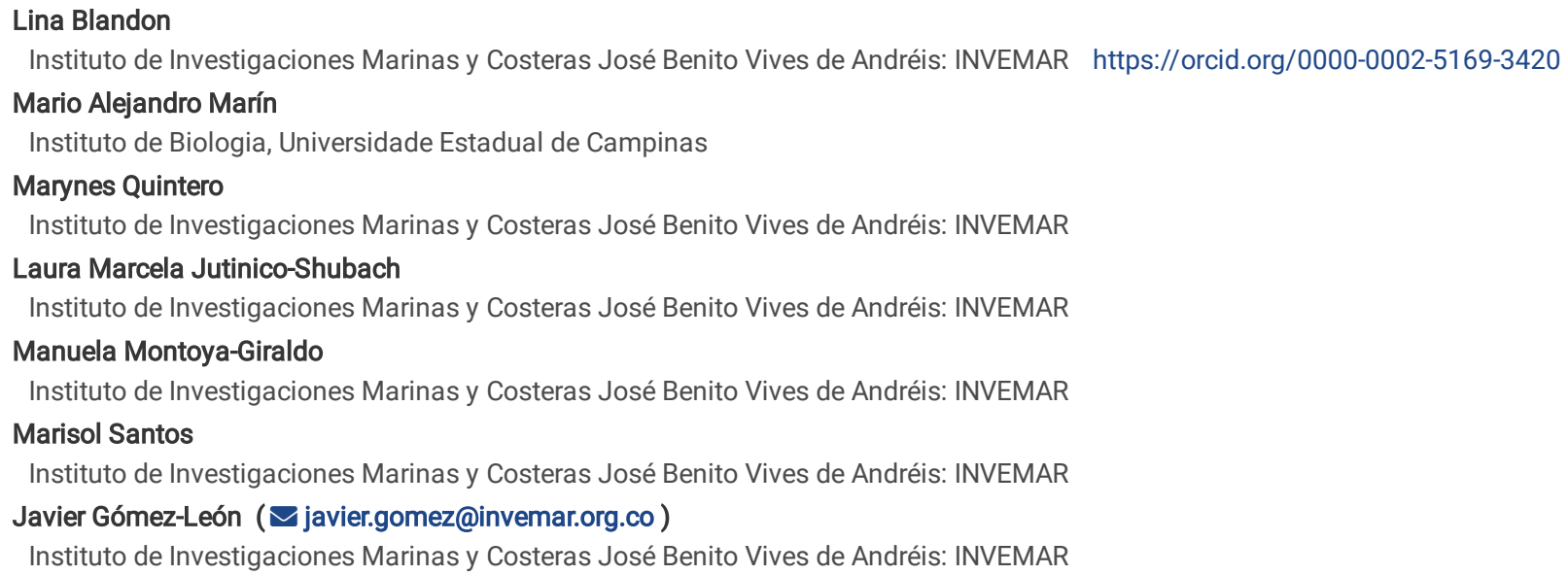

Version of Record: A version of this preprint was published at Antonie van Leeuwenhoek on January 23rd, 2022. See the published version at https://doi.org/10.1007/s10482-021-01706-4. 


\section{Abstract}

The diversity of deep-sea cultivable bacteria was studied in seven sediment samples of the Colombian Caribbean. Three hundred and fifty two marine bacteria were isolated according to its distinct morphological character on the solid media, then DNA sequences of the 16S rRNA were amplified to identify the isolated strains. The identified bacterial were arranged in three phylogenetic groups, Firmicutes, Proteobacteria, and Actinobacteria, with 34 different OTUs defined at $\geq 97 \%$ of similarity and 70 OTUs at $\geq 98.65 \%$, being the $51 \%$ Firmicutes, $34 \%$ Proteobacteria and $15 \%$ Actinobacteria. Bacillus and Fictibacillus were the dominant genera in Firmicutes, Halomonas and Pseudomonas in Proteobacteria and Streptomyces and Micromonospora in Actinobacteria. In addition, the strains were tested for biosurfactants and lipases production, with 120 biosurfactant producing strains (mainly Firmicutes) and, 56 lipases producing strains (Proteobacteria). This report contributes to the understanding of the detailed physiology and the complex environmental processes associated with the marine deep-sea cultivable bacteria from the Colombian Caribbean.

\section{Introduction}

The ecological importance of bacteria in deep-sea sediments has been recognized since 1957, when Zobell and Morita (1957) isolated marine piezophiles. In deep-sea ecosystems, microbial communities contribute to global carbon recycling and represent Earth's major ecological research frontier (Danovaro et al., 2014). Specifically, deep-sea sediments are substrates for bacterial growth because of its vast matrix of organic molecules mainly composed by carbon (C), nitrogen (N), and phosphorus (P) (Jamieson et al., 2013). However, the availability of these organic pools is highly variable geographically and depends on their origin, degradation rates, and utilization by benthic consumers (Li et al., 1999).

The Caribbean Sea is a semi-enclosed basin of the western Atlantic Ocean, it is bounded by the coasts of Central and South America on two sides and by the Antilles island chain and the arc of the Greater and Lesser Antilles. It has an average depth of $2400 \mathrm{~m}$ being a $75 \% \mathrm{more}$ deeper than $1800 \mathrm{~m}$ approximately (Hernández-Ávila, 2014). The Caribbean seafloor include typical abyssal soft-sediment extensions, numerous small canyons, and wide (10 km) and low-relief channels. It is divided into five deep-sea areas: The Grenada, Venezuelan, Colombian, and Yucatan Basins and the Cayman Trough, separated from each other by underwater ridges and sills (Miloslavich et al., 2010).

With the development of environmental DNA technology (Olsen et al., 1986; Pace et al., 1986), it was possible to study an unexplored diversity making the study of deep-sea environments a challenge in the field of ecology and evolution of microbial communities. In this sense, DNA sequences supply the tools to study the communities, especially gene encoding rRNAs providing a basis to estimate phylogenetic diversity and generate taxonomic inventories of microbial populations (Kai et al., 2017; Rappé \& Giovannoni, 2003). Additionally, the analysis of 16S rRNA gene libraries have shown that there is a substantial diversity of bacteria in deep-sea sediments, both within and between the phyla (Fry et al., 2008), with a high variation of beta-diversity, reflecting the physical, chemical and biological contrasts in deep-sea ecosystems (Zinger et al., 2011).

Worldwide, significant efforts have been made to cultivate marine microorganisms from deep-sea environments under controlled laboratory conditions, obtaining a low representation of these. Nevertheless, the few representatives available are highly valuable for discovering information about unusual types of metabolism, pressure and temperature adaptations, and growth under "extreme" conditions (Orcutt et al., 2011); also, marine microorganisms can be a source of unique metabolites for many industrial and environmental (bioremediation) applications.

The aim of this study was to describe the phylogenetic diversity of the piezotolerant cultivable bacterial community from deep-sea sediments, identify the abundant and significant types of different bacteria, and explore its bioremediation capacity.

\section{Materials And Methods}

\subsection{Sample collection and Bacteria isolation}

Marine deep sediments were collected using a box corer in 7 stations of the Colombian Caribbean Sea (Figure 1), during the cruises to the blocks COL1, COL2, COL3, and COL10 conducted by the National Hydrocarbon Agency (ANH) (Vides et al., 2017;). Samples were preserved at $4^{\circ} \mathrm{C}$ until they were processed in the Marine Bioprospecting Laboratory - LabBIM at INVEMAR.

For bacteria isolation, $20 \mathrm{~g}$ of sediments were resuspended in $90 \mathrm{~mL}$ of peptone water with $1 \%$ of $\mathrm{NaCl}$. Then, serial dilutions were made and $0.1 \mathrm{~mL}$ of each one were taken to cultivate by the spread plate method using different media (Table S1). The cultures were maintained at a range of temperatures between 4 to $70^{\circ} \mathrm{C}$ under aerobic and anaerobic conditions during $8-30$ days depending on the microbial growth observed (Table S1). Finally, the colonies that presented distinctive morphologies were selected. Axenic cultures were obtained through various subcultures in the same culture media where the strains were initially selected. A voucher and all associated information of each collected specimen was deposited at the Marine Museum of Natural History of ColombiaMakuriwa, where identification codes were assigned.

\subsection{Bacteria classification and diversity}

Bacteria classification was based on the analysis of 16S rRNA gene sequencing using the universal primers 27F / 1492R (Lane, 1991). Genomic DNA was extracted using the Invitrogen PureLink Genomic DNA kit. The DNA from all the purified isolates was used for PCR amplification of the 16S rRNA gene, then, the PCR - amplified products were subjected to sequencing by the Sanger method at National Center for Genomic Sequencing (Medellín, Colombia) reading both chains.

The sequence analysis and taxonomy were performed in the SILVA ribosomal RNA database project using the web resources for alignment, classification and tree services (SILVA-ACT) (https://www.arb-silva.de/aligner/) (Glöckner et al., 2017; Quast et al., 2013). 16S rRNA sequences were aligned using SINA (SILVA 
Incremental Aligner v1.2.11) that uses a combination of k-mer sequence search and partial order alignment (POA) to maintain very high alignment accuracy of rRNA gene sequences (Pruesse et al., 2012).

The genetic diversity of cultured bacteria was estimated by cluster analyses in Mothur v.1.40.5 (https://www.mothur.org/wiki/Main_Page) (Schloss et al., 2009), using various levels of sequence identity between $80 \%$ and $100 \%$. For the definition of operational taxonomic units (OTUs) two limits were adopted, the standard limit of $97 \%$ of similarity and the recommended cut-off of $98.65 \%$ (Kim, 2014; Mysara et al., 2017). Phylogenetic trees were constructed using Maximum Likelihood (ML) method, implemented in RAxML-HPC2 v8.2.10 (Stamatakis, 2014), on the CIPRES Science Gateway portal v3.3 (https://www.phylo.org/) (Miller et al., 2010), under generalized time-reversible (GTR $+\Gamma$ ) model and 100 heuristic independent runs. For bootstrapping, we performed 1000 pseudo-replicates analyses; this was performed under auto Majority Rule Criterion (autoMRE).

The identity of the sequences was compared with reference taxonomies hosted by SILVA-ACT (RDP, EMBL-EBI/ENA and SILVA) (Cole et al., 2014; Quast et al., 2013; Toribio et al. 2017), using the least common ancestor (LCA) method and searching five of the nearest sequences with a similarity superior at $99 \%$.

\subsection{Biosurfactants and lipases production detection}

The oil - spreading test was made to detect the production of extracellular biosurfactant. Briefly, $20 \mu \mathrm{L}$ of oil crude were poured over $40 \mathrm{~mL}$ of distilled water in a petri dish. Then $20 \mu \mathrm{L}$ of cell-free culture were added carefully in the center of the layer, the diameter of spreading was measured in mm. As negative control was used $20 \mu \mathrm{L}$ of the broth without inoculum, and as positive control of displacement $20 \mu \mathrm{L}$ of neutral detergent (Extran ${ }^{\circledR}$ MA 02$)$, each one in different petri dishes. The assay was done by triplicate. It was considered as positive result, the spreading of the crude oil and a zone of emulsification on the surface (Walter et al., 2013).

Lipase activity was evaluated on staining fat emulsion agar using Nile blue A as indicator and olive oil as substrate. The cultures were incubated at $30^{\circ} \mathrm{C}$ for 3 7 days and Pseudomonas aeruginosa ATCC 10145 was used as positive control. The observation of blue colonies surrounded by decolorate and transparent zones was an indication of positive strains for lipase production, whereas no lipolitic strains were observed as white and rose (Eisenberg, 1939).

\section{Results}

\subsection{Sample collection and Bacteria isolation}

Three hundred and fifty-two cultivable bacteria were isolated from deep-sea sediments in seven stations E553 (1254 m), E568 (2106 m), E428 (3186 m), E466 (3328 m), E603 (3474 m), E617 (3704 m), E612 (4220 m). Initially, all the isolates were identified based on the different colony characteristics. The stations with most isolated strains were E603 (56), E617 (50), and E612 (44) which were the more farthest from the coast, followed by E428 (35), E466 (30), E553 (25), and E568 (22) (Table S2).

\subsection{Bacteria classification and diversity}

The 16S rRNA gene of the cultivable bacteria isolated were sequenced with an average length of $1352 \mathrm{bp}$. Thirty-four OTUs were defined at $\geq 97 \%$ and seventy at $\geq 98.65 \%$ of similarity (Table S2). The bacterial assemblage was arranged in three phylogenetic groups, Proteobacteria, Actinobacteria (Gram-positives with high $\mathrm{G}+\mathrm{C}$ percentage), and Firmicutes (Gram-positives with low G+C percentage) (Figure 2). The OTUs composition was $51 \%$ Firmicutes, $34 \%$ Proteobacteria and $15 \%$ Actinobacteria. Bacillus and Fictibacillus were the dominant genera in Firmicutes, Halomonas and Pseudomonas in Proteobacteria and Streptomyces and Micromonospora in Actinobacteria (Figure 3).

The bacteria were identified and related with isolates previously registered in the databases of taxonomic references (RDP, EMBL-EBI/ENA and SILVA). Most of the isolated belonged to the phylum Firmicutes, followed by Proteobacteria (Figure 3A). Several interesting and recently described genera were identified, such as Piscibacillus (Tanasupawat et al., 2007), Lysinibacillus (Ahmed et al., 2007), Fictibacillus (Glaeser et al., 2013), Aquibacillus (Amoozegar et al., 2014), Domibacillus (Seiler et al., 2013), Idiomarina (Ivanova et al., 2000), Cellulosimicrobium (Schumann et al., 2001), Cobetia (Arahal et al., 2002), Paenisporosarcina (Krishnamurthi et al., 2009), and Plantactinospora (Qin et al., 2009) (Figure 3B, Table S2).

\subsection{Biosurfactants and lipases extracellular production detection}

One hundred and twenty isolated strains were identified as biosurfactant producers by the oil-spreading test. The majority of the promising biosurfactant producers belong to the Firmicutes ( 85 strains) and the station with the most biosurfactant producing strains was the deepest E612 (4220 $\mathrm{m}$ ) ( 33 ). On the other hand, a less number of strains (56) were identified as lipase producers, the majority belongs to the Proteobacteria (29), followed by Firmicutes (23), and the majority of the lipase producing strains were from the station E603 (3474 m) the farthest from the coast. In addition, 20 strains showed capacity to produce both biosurfactants and lipases, specifically from the species Alteromonas sp., Pseudomonas sp. , Micromonospora sp., Bacillus sp., Halomonas sp, Chromohalobactersp., Cobetia sp., Fictibacillus sp., Paenibacillus sp., and Domibacillus sp. (Figure 4, Table S3).

\section{Discussion}

The sampling stations E466, E428, E568, E553 (Figure 1) are located in the central part of the Colombian basin, in front of the coastline between the Tayrona National Park in the Magdalena Department, covering an area of 2.500 .000 ha. The approximate minimum distance to the coast is $60 \mathrm{mn}$ and the maximum is $160 \mathrm{mn}$, covering depths from 2100 to $4500 \mathrm{mn}$ that is the most extensive geomorphological feature within the Caribbean Large Ecosystem (Vides \& Alonso, 2016). The four stations are highly influenced by the delta of the Magdalena River, presenting changes in the water composition in hundreds of kilometers inside the sea contributing with a high quantity of sediments in suspension $\left(142.6 \times 10^{6} \mathrm{t} \mathrm{a}^{-1}\right)$ with a sedimentation rate $\leq 1.430 \mathrm{~mm} \mathrm{a}^{-1}$ in the 
deepest areas of the delta front (Restrepo et al., 2015). This change in the water composition also might cause complex hydraulic phenomena, such as the conformation of a submarine delta composed of submarine sediment bars (Castaño-Uribe et al., 2003). On the other hand, the sampling stations E603, E612, and E617 (Figure 1) are located on the northeastern extreme of Colombia's marine territory on the Caribbean Basin. It also includes a portion of the Beata Ridge, an underwater ridge of the south bed of the Caribbean Sea (Vides et al, 2018).

For the definition of OTUs, the cut-off at $\geq 98.65 \%$ are biologically most representative according to the bacterial community (Figure 3 ). This result agrees with the proposed by Kim et al. (2014), who calculated this value based in the complete sequence of the 16S gene allowing a more accurate estimation of the microbial diversity. In this study, 352 cultivable bacteria were isolated by classic microbiology techniques; these strains tolerate the sudden change of pressure, so they can be cataloged as piezotolerant (Velásquez et al., 2018). The cultivation of microbes is still necessary, because it contributes to the comprehensive understanding of the detailed physiology and the complex environmental processes associated with them. Likewise, this is the first step for the microbes to be applied on environmental remediation, energy and pharmaceutical industry. In addition, these cultures can provide complete genomes and the means to verify potential metabolic ability or ecosystem function (Zhang et al., 2018).

The hypothetical difference between marine and terrestrial microorganisms derives from salinity an important factor for microbial growth, osmotic regulation in fresh and marine water is completely different (Sivaperumal et al., 2017). Besides, the marine bacterial communities seem significantly influenced by depth and the distance from the coast. The most abundant Phylum in all stations was Firmicutes except for E603 (Figure 3A), which is the station farthest from the coast. The majority of the species from the Firmicutes are related to endospore-forming bacteria (EFB). The ability to produce endospores and the great metabolic and physiological diversity are two characteristics of the EFB that allow their distribution in all environments (da Silva et al., 2013). Likewise, the sporulation allows EFB to tolerate different environmental conditions and constitute a seed bank that allows populations to persist over longer time scales and thereby maintain biodiversity in an environment (Cupit et al., 2019).

Of the nine families of Firmicutes, the Bacillaceae and the Planococcaceae are the largest taxa. Members of the family Bacillaceae are reported as Gram positive, rod-shaped, endospore forming and moderately halophilic some have been isolated from marine environments (Lu et al., 2001), fermented fishfoods (Tanasupawat et al., 2007) and salt lakes (Amoozegar et al., 2014). Within this family, one of the most common genus is Bacillus. In this study, Bacillus strains were the most commonly found (Figure 3B), specifically, the station E553 had the highest abundance of strains. This is in concordance with the fact that Bacillus strains needs more nutrition (Mondol et al., 2013) and the delta of the Magdalena River influences these stations, probably contributing with organic material. The members of Bacillus genus are known to be halotolerant, alkalitolerant and/or alkaliphilic (Glaeser et al., 2013). In addition, few members of the family Planococcaceae were isolated, they belong to the genus Paenisporosarcina. The Paenisporosarcina genus has been recently described, this genus is close to the genus Sporosarcina, its members are Gram positive rods and/or cocci, non-motile, strictly aerobic, and form round endospores (Krishnamurthi et al., 2009)

The Proteobacteria and Firmicutes phylum have been reported as the most known and readily cultivable microorganisms from the marine environment (da Silva et al., 2013; Ettoumi et al., 2010; Fuhrman \& Hagström, 2008; Kai et al., 2017; Orcutt et al., 2011; Velmurugan et al., 2011; Zhang et al., 2018). In this study, the Proteobacteria phylum was the second in abundance, the majority of the Proteobacteria strains were isolated in the station E603 (Figure 1 and $3 \mathrm{~A}$ ), which is farthest of the coast. Proteobacteria is known to have the largest divisions within the prokaryotes, this group is divided into five classes designated as a, $\beta$, $\gamma, \delta$, and $\varepsilon$, also this phylum is known to have a major proportion of Gram negative organisms (Gupta, 2000). Due to its halotolerance nature a great number of marine bacteria, belong to the Alteronomas, Pseudoalteromonas and Halomonas species. In this study, the most common Proteobacteria isolated species belong to the Halomonas genus, this genus was first described by Vreeland et al., (1980), they are part of the Gammaproteobacteria class, and its members are described as rod-shaped, halophilic or halotolerant, aerobic or anaerobic (Vreeland et al., 1980). Finally, the third phylum found in this study is Actinobacteria. These are aerobic, Gram positive and non-motile bacteria, with high guanosine-cytosine content in their DNA (70-80\%). Actinobacteria members are commonly found in terrestrial soils, but recently some studies reported the isolation of Actinobacteria from coastal environments like mangrove swamps and deep sea sediments, as this study (Jose et al., 2021).

Regarding the marine environment extreme conditions (low temperatures, alkaline $\mathrm{pH}$, high tolerance to saline conditions, and high pressure), marine microorganisms could produce unique metabolites. In this study, the isolated strains were tested for the production of biosurfactants and lipases important compounds for bioremediation applications. One hundred and twenty strains were found as biosurfactant producers the majority belong from the Firmicutes phylum (85), followed by Proteobacterias (29) and a few members of the Actinobacteria phylum (4) (Figure 4 and Table S3). Besides, the majority of the biosurfactant producing strains belong to the deepest station E612 (4220 m).

Biosurfactants are amphiphilic surface-active molecules commonly produced as consequence of the presence of complex water insoluble substrates like hydrocarbons, also, they are involved in other biological functions such as microbial competition and intra or inter-species communication (Ibacache-Quiroga et al., 2013). In addition to the hydrocarbons degradation, biosurfactants could replace the surfactants used in pesticides and, at the same time, improving the quality of the soil through the improvement of the bioremediation process degrading hydrocarbons as well as heavy metals (Drakontis \& Amin, 2020). Firmicutes members like Bacillus have been reported as biosurfactant producers, in this study the majority of the biosurfactant producing strains are Bacillus sp. as well as Proteobacteria species like Pseudomonas, which have been also highly reported (Mishra et al., 2021).

Furthermore, in comparison to the enzymes derived from terrestrial fonts the enzymes from marine microorganisms has some advantages like temperature and solvent stability, various catalyzing activities, high production in less time, and they are easy to harvest (Sivaperumal et al., 2017). In this sense, 56 strains were identified as lipases producers, the majority belong to the Proteobacteria phylum (29) followed by Firmicutes (23), and just 2 members of the Actinobacteria phylum a Micromonospora sp. and a Prauserella sp.(Figure 4 and table S3). Lipases are hydrolases that catalyze triglycerides to fatty acids and glycerol. In marine environments, lipase production are related to the mineralization of complex organic matter, probably as consequence of the 
degradation of dead plant and animals (Patnala et al., 2016), lipases are useful in many industries like detergent, pharmaceutical, food, as well as in bioremediation by the degradation of contaminants like dimethylphthalate (Mita et al., 2010) and oil (Basha, 2021).

In conclusion, 352 marine cultivable bacteria were isolated from deep-sediment samples from the Colombian Caribbean finding the phylum Firmicutes as the predominant, 120 were found as biosurfactant and 56 as lipases producing strains. This study highlights the fact that a great deal remains to be learned about the bacterial diversity present in these ecosystems and its potential in bioremediation.

\section{Declarations}

\section{Funding}

Thanks to the National Hydrocarbon Agency - ANH and to the Marine and Coastal Research institute "José Benito Vives de Andréis" - INVEMAR for the financial support.

Thanks to the information analysis laboratory -LABSIS at Marine and Coastal Research Institute "José Benito Vives de Andréis"-INVEMAR, for making the map (Figure 1)

M.A.M. acknowledges FAPESP for the Pos-Doc fellowship (2018/11910-1) and CAPES (Finance code 001).

\section{Author contributors}

Lina Marcela Blandón and Mario Alejandro Marín: Writing-original draft preparation, Marynes Quintero, Manuela Montoya -Giraldo and Laura Marcela Jutinico - Shubach: Conceptualization, Methodology, data curation, Marisol Santos - Acevedo and Javier Gómez - León: Supervision, reviewing.

\section{Conflict of interest}

The authors did not report any potential conflict of interest. All the authors have approved the final manuscript. The authors declare that this manuscript has not been published previously.

\section{Statement}

This research was carried out within the framework of the contract (Contrato marco de acceso a recursos genéticos y sus productos derivados 123 número RGE 0158-5) granted to the Marine and Coastal Research Institute "José Benito Vives de Andréis - INVEMAR by the Ministerio de Ambiente y Desarrollo Sostenible de Colombia (Minambiente).

\section{References}

Ahmed, I., Yokota, A., Yamazoe, A., \& Fujiwara, T. (2007). Proposal of Lysinibacillus boronitolerans gen. Nov. Sp. Nov., and transfer of Bacillus fusiformis to Lysinibacillus fusiformis comb. Nov. and Bacillus sphaericus to Lysinibacillus sphaericus comb. Nov. International Journal of Systematic and Evolutionary Microbiology, 57(5), 1117-1125. https://doi.org/10.1099/ijs.0.63867-0

Amoozegar, M. A., Bagheri, M., Didari, M., Mehrshad, M., Schumann, P., Spröer, C., Sánchez-Porro, C., \& Ventosa, A. (2014). Aquibacillus halophilus gen. Nov., sp. Nov., a moderately halophilic bacterium from a hypersaline lake, and reclassification of Virgibacillus koreensis as Aquibacillus koreensis comb. Nov. and Virgibacillus albus as Aquibacillus albus comb. Nov. International Journal of Systematic and Evolutionary Microbiology, 64(Pt_11), 3616-

3623. https://doi.org/10.1099/ijs.0.065375-0

Arahal, D. R., Castillo, A. M., Ludwig, W., Schleifer, K. H., \& Ventosa, A. (2002). Proposal of Cobetia marina gen. Nov., comb. Nov., within the Family Halomonadaceae, to include the Species Halomonas marina. Systematic and Applied Microbiology, 25(2), 207-211. https://doi.org/10.1078/0723-202000113

Basha, P. A. (2021). Chapter 25-Oil degrading lipases and their role in environmental pollution. En B. Viswanath (Ed.), Recent Developments in Applied Microbiology and Biochemistry (pp. 269-277). Academic Press. https://doi.org/10.1016/B978-0-12-821406-0.00025-4

Castaño-Uribe, C., Riedel, S., Gómez, F., \& Montes-Veira, S. (2003). Río grande de la Magdalena. Banco de

Occidente. http://imeditores.com/banocc/rio/presentacion.htm

Cole, J. R., Wang, Q., Fish, J. A., Chai, B., McGarrell, D. M., Sun, Y., Brown, C. T., Porras-Alfaro, A., Kuske, C. R., \& Tiedje, J. M. (2014). Ribosomal Database Project: Data and tools for high throughput rRNA analysis. Nucleic Acids Research, 42(D1), D633-D642. https://doi.org/10.1093/nar/gkt1244

Cupit, C., Lomstein, B. A., \& Kjeldsen, K. U. (2019). Contrasting community composition of endospores and vegetative Firmicutes in a marine sediment suggests both endogenous and exogenous sources of endospore accumulation. Environmental Microbiology Reports, 11(3), 352-

360. https://doi.org/10.1111/1758-2229.12679

da Silva, M. A. C., Cavalett, A., Spinner, A., Rosa, D. C., Jasper, R. B., Quecine, M. C., Bonatelli, M. L., Pizzirani-Kleiner, A., Corção, G., \& Lima, A. O. de S. (2013). Phylogenetic identification of marine bacteria isolated from deep-sea sediments of the eastern South Atlantic Ocean. SpringerPlus, 2(1), 127. https://doi.org/10.1186/2193-1801-2-127 
Danovaro, R., Snelgrove, P. V. R., \& Tyler, P. (2014). Challenging the paradigms of deep-sea ecology. Trends in Ecology \& Evolution, 29(8), 465475. https://doi.org/10.1016/j.tree.2014.06.002

Drakontis, C. E., \& Amin, S. (2020). Biosurfactants: Formulations, properties, and applications. Current Opinion in Colloid \& Interface Science, 48, 7790. https://doi.org/10.1016/j.cocis.2020.03.013

Eisenberg, G. M. (1939). A Nile Blue Culture Medium for Lipolytic Microorganisms. Stain Technology, 14(2), 6367. https://doi.org/10.3109/10520293909110300

Ettoumi, B., Bouhajja, E., Borin, S., Daffonchio, D., Boudabous, A., \& Cherif, A. (2010). Gammaproteobacteria occurrence and microdiversity in Tyrrhenian Sea sediments as revealed by cultivation-dependent and -independent approaches. Systematic and Applied Microbiology, 33(4), 222-

231. https://doi.org/10.1016/j.syapm.2010.02.005

Fry, J. C., Parkes, R. J., Cragg, B. A., Weightman, A. J., \& Webster, G. (2008). Prokaryotic biodiversity and activity in the deep subseafloor biosphere. FEMS Microbiology Ecology, 66(2), 181-196. https://doi.org/10.1111/j.1574-6941.2008.00566.x

Fuhrman, J. A., \& Hagström, Å. (2008). Bacterial and Archaeal Community Structure and its Patterns. En Microbial Ecology of the Oceans (pp. 45-90). John Wiley \& Sons, Ltd. https://doi.org/10.1002/9780470281840.ch3

Glaeser, S. P., Dott, W., Busse, H.-J., \& Kämpfer, P. 2013. (2013). Fictibacillus phosphorivorans gen. Nov., sp. Nov. And proposal to reclassify Bacillus arsenicus, Bacillus barbaricus, Bacillus macauensis, Bacillus nanhaiensis, Bacillus rigui, Bacillus solisalsi and Bacillus gelatini in the genus Fictibacillus. International Journal of Systematic and Evolutionary Microbiology, 63(Pt_8), 2934-2944. https://doi.org/10.1099/ijs.0.049171-0

Glöckner, F. O., Yilmaz, P., Quast, C., Gerken, J., Beccati, A., Ciuprina, A., Bruns, G., Yarza, P., Peplies, J., Westram, R., \& Ludwig, W. (2017). 25 years of serving the community with ribosomal RNA gene reference databases and tools. Journal of Biotechnology, 261, 169-176. https://doi.org/10.1016/j.jbiotec.2017.06.1198

Gupta, R. S. (2000). The phylogeny of proteobacteria: Relationships to other eubacterial phyla and eukaryotes. FEMS Microbiology Reviews, 24(4), 367402. https://doi.org/10.1016/S0168-6445(00)00031-0

Hernández-Ávila, I. (2014). Patterns of Deep-Water Coral Diversity in the Caribbean Basin and Adjacent Southern Waters: An Approach based on Records from the R/V Pillsbury Expeditions. PLoS ONE, 9(3), e92834. https://doi.org/10.1371/journal.pone.0092834

Ibacache-Quiroga, C., Ojeda, J., Espinoza-Vergara, G., Olivero, P., Cuellar, M., \& Dinamarca, M. A. (2013). The hydrocarbon-degrading marine bacterium Cobetia sp. Strain MM1IDA2H-1 produces a biosurfactant that interferes with quorum sensing of fish pathogens by signal hijacking. Microbial Biotechnology, 6(4), 394-405. https://doi.org/10.1111/1751-7915.12016

Ivanova, E. P., Romanenko, L. A., Chun, J., Matte, M. H., Matte, G. R., Mikhailov, V. V., Svetashev, V. I., Huq, A., Maugel, T., \& Colwell, R. R. 2000. (2000). Idiomarina gen. Nov., comprising novel indigenous deep-sea bacteria from the Pacific Ocean, including descriptions of two species, Idiomarina abyssalis sp. Nov. and Idiomarina zobellii sp. Nov. International Journal of Systematic and Evolutionary Microbiology, 50(2), 901-907. https://doi.org/10.1099/00207713-50-2-901

Jamieson, R. E., Heywood, J. L., Rogers, A. D., Billett, D. S. M., \& Pearce, D. A. (2013). Bacterial biodiversity in deep-sea sediments from two regions of contrasting surface water productivity near the Crozet Islands, Southern Ocean. Deep Sea Research Part I: Oceanographic Research Papers, 75, 6777. https://doi.org/10.1016/j.dsr.2012.12.012

Jose, P. A., Maharshi, A., \& Jha, B. (2021). Actinobacteria in natural products research: Progress and prospects. Microbiological Research, 246, 126708. https://doi.org/10.1016/j.micres.2021.126708

Kai, W., Peisheng, Y., Rui, M., Wenwen, J., \& Zongze, S. (2017). Diversity of culturable bacteria in deep-sea water from the South Atlantic Ocean. Bioengineered, 8(5), 572-584. https://doi.org/10.1080/21655979.2017.1284711

Kim, S.-K. (2014). Handbook of Anticancer Drugs from Marine Origin. Springer.

Krishnamurthi, S., Bhattacharya, A., Mayilraj, S., Saha, P., Schumann, P., \& Chakrabarti, T. Y. 2009. (2009). Description of Paenisporosarcina quisquiliarum gen. Nov., sp. Nov., and reclassification of Sporosarcina macmurdoensis Reddy et al. 2003 as Paenisporosarcina macmurdoensis comb. Nov. International Journal of Systematic and Evolutionary Microbiology, 59(6), 1364-1370. https://doi.org/10.1099/ijs.0.65130-0

Lane, D. (1991). 16S/23S rRNA Sequencing. En E. Stackebrandt \& M. Goodfellow (Eds.), Nucleic Acid Techniques in Bacterial Systematics. (pp. 115-175). Wiley.

Li, L., Kato, C., \& Horikoshi, K. (1999). Bacterial diversity in deep-sea sediments from different depths. Biodiversity \& Conservation, 8(5), 659-

677. https://doi.org/10.1023/A:1008848203739

Lu, J., Nogi, Y., \& Takami, H. (2001). Oceanobacillus iheyensis gen. Nov., sp. Nov., a deep-sea extremely halotolerant and alkaliphilic species isolated from a depth of 1050 m on the Iheya Ridge. FEMS Microbiology Letters, 205(2), 291-297. https://doi.org/10.1111/j.1574-6968.2001.tb10963.x

Miller, M., Pfeiffer, W., \& Schwartz, T. (2010). Creating the CIPRES Science Gateway for inference of large phylogenetic trees. 2010 Gateway Computing Environments Workshop (GCE). https://doi.org/10.1109/GCE.2010.5676129

Page 6/10 
Miloslavich, P., Díaz, J. M., Klein, E., Alvarado, J. J., Díaz, C., Gobin, J., Escobar-Briones, E., Cruz-Motta, J. J., Weil, E., Cortés, J., Bastidas, A. C., Robertson, R., Zapata, F., Martín, A., Castillo, J., Kazandjian, A., \& Ortiz, M. (2010). Marine Biodiversity in the Caribbean: Regional Estimates and Distribution Patterns. PLoS ONE, 5(8), e11916. https://doi.org/10.1371/journal.pone.0011916

Mishra, S., Lin, Z., Pang, S., Zhang, Y., Bhatt, P., \& Chen, S. (2021). Biosurfactant is a powerful tool for the bioremediation of heavy metals from contaminated soils. Journal of Hazardous Materials, 418, 126253. https://doi.org/10.1016/j.jhazmat.2021.126253

Mita, L., Sica, V., Guida, M., Nicolucci, C., Grimaldi, T., Caputo, L., Bianco, M., Rossi, S., Bencivenga, U., Eldin, M. S. M., Tufano, M. A., Mita, D. G., \& Diano, N. (2010). Employment of immobilised lipase from Candida rugosa for the bioremediation of waters polluted by dimethylphthalate, as a model of endocrine disruptors. Journal of Molecular Catalysis B: Enzymatic, 62(2), 133-141. https://doi.org/10.1016/j.molcatb.2009.09.016

Mondol, M. A. M., Shin, H. J., \& Islam, M. T. (2013). Diversity of Secondary Metabolites from Marine Bacillus Species: Chemistry and Biological Activity. Marine Drugs, 11(8), 2846-2872. https://doi.org/10.3390/md11082846

Mysara, M., Vandamme, P., Props, R., Kerckhof, F.-M., Leys, N., Boon, N., Raes, J., \& Monsieurs, P. (2017). Reconciliation between operational taxonomic units and species boundaries. FEMS Microbiology Ecology, 93(4). https://doi.org/10.1093/femsec/fix029

Olsen, G. J., Lane, D. J., Giovannoni, S. J., Pace, N. R., \& Stahl, D. A. (1986). Microbial ecology and evolution: A ribosomal RNA approach. Annual Review of Microbiology, 40, 337-365. https://doi.org/10.1146/annurev.mi.40.100186.002005

Orcutt, B. N., Sylvan, J. B., Knab, N. J., \& Edwards, K. J. (2011). Microbial Ecology of the Dark Ocean above, at, and below the Seafloor. Microbiology and Molecular Biology Reviews: MMBR, 75(2), 361-422. https://doi.org/10.1128/MMBR.00039-10

Pace, N. R., Stahl, D. A., Lane, D. J., \& Olsen, G. J. (1986). The Analysis of Natural Microbial Populations by Ribosomal RNA Sequences. En K. C. Marshall (Ed.), Advances in Microbial Ecology (pp. 1-55). Springer US. https://doi.org/10.1007/978-1-4757-0611-6_1

Patnala, H. S., Kabilan, U., Gopalakrishnan, L., Rao, R. M. D., \& Kumar, D. S. (2016). Marine Fungal and Bacterial Isolates for Lipase Production: A Comparative Study. Advances in Food and Nutrition Research, 78, 71-94. https://doi.org/10.1016/bs.afnr.2016.06.001

Pruesse, E., Peplies, J., \& Glöckner, F. O. (2012). SINA: Accurate high-throughput multiple sequence alignment of ribosomal RNA genes. Bioinformatics, 28(14), 1823-1829. https://doi.org/10.1093/bioinformatics/bts252

Qin, S., Li, J., Zhang, Y.-Q., Zhu, W.-Y., Zhao, G.-Z., Xu, L.-H., \& Li, W.-J. (2009). Plantactinospora mayteni gen. Nov., sp. Nov., a member of the family Micromonosporaceae. International Journal of Systematic and Evolutionary Microbiology, 59(10), 2527-2533. https://doi.org/10.1099/ijs.0.010793-0

Quast, C., Pruesse, E., Yilmaz, P., Gerken, J., Schweer, T., Yarza, P., Peplies, J., \& Glöckner, F. O. (2013). The SILVA ribosomal RNA gene database project: Improved data processing and web-based tools. Nucleic Acids Research, 41(D1), D590-D596. https://doi.org/10.1093/nar/gks1219

Rappé, M. S., \& Giovannoni, S. J. (2003). The uncultured microbial majority. Annual Review of Microbiology, 57, 369-

394. https://doi.org/10.1146/annurev.micro.57.030502.090759

Restrepo, J. C., Schrottke, K., Orejarena, A., Ortiz, J., Higgins, A., Otero, L., \& Marriaga, L. (2015). Transporte de sedimentos y ajustes morfológicos en un delta tropical de alta descarga (Río Magdalena, Colombia): Evidencias de un periodo de cambio e intervención antrópica (1990-2010). XVI,

72. http://www.colacmar-senalmar2015.com/es/pdf/LibroMemorias_Senalmar_Final.pdf

Seiler, H., Wenning, M., \& Scherer, S. (2013). Domibacillus robiginosus gen. Nov., sp. Nov., isolated from a pharmaceutical clean room. International Journal of Systematic and Evolutionary Microbiology, 63(Pt 6), 2054-2061. https://doi.org/10.1099/ijs.0.044396-0

Schloss, P. D., Westcott, S. L., Ryabin, T., Hall, J. R., Hartmann, M., Hollister, E. B., Lesniewski, R. A., Oakley, B. B., Parks, D. H., Robinson, C. J., Sahl, J. W., Stres, B., Thallinger, G. G., Horn, D. J. V., \& Weber, C. F. (2009). Introducing mothur: Open-Source, Platform-Independent, Community-Supported Software for Describing and Comparing Microbial Communities. Applied and Environmental Microbiology, 75(23), 7537-7541. https://doi.org/10.1128/AEM.01541-09

Schumann, P., Weiss, N., \& Stackebrandt, E. 2001. (2001). Reclassification of Cellulomonas cellulans (Stackebrandt and Keddie 1986) as Cellulosimicrobium cellulans gen. Nov., comb. Nov. International Journal of Systematic and Evolutionary Microbiology, 51(3), 1007-1010. https://doi.org/10.1099/00207713-51-31007

Sivaperumal, P., Kamala, K., \& Rajaram, R. (2017). Bioremediation of Industrial Waste Through Enzyme Producing Marine Microorganisms. En Advances in Food and Nutrition Research (1. ${ }^{\text {a }}$ ed., Vol. 80, p. 216). Elsevier.

Stamatakis, A. (2014). RAxML version 8: A tool for phylogenetic analysis and post-analysis of large phylogenies. Bioinformatics (Oxford, England), 30(9), 1312-1313. https://doi.org/10.1093/bioinformatics/btu033

Tanasupawat, S., Namwong, S., Kudo, T., \& Itoh, T. (2007). Piscibacillus salipiscarius gen. Nov., sp. Nov., a moderately halophilic bacterium from fermented fish (pla-ra) in Thailand. International Journal of Systematic and Evolutionary Microbiology, 57(7), 1413-1417. https://doi.org/10.1099/ijs.0.64945-0

Toribio, A. L., Alako, B., Amid, C., Cerdeño-Tarrága, A., Clarke, L., Cleland, I., Fairley, S., Gibson, R., Goodgame, N., Hoopen, P. T., Jayathilaka, S., Kay, S., Leinonen, R., Liu, X., Martínez-Villacorta, J., Pakseresht, N., Rajan, J., Reddy, K., Rosello, M., Silvester, N., Smirnov, D., Vaughan, D., Zalunin, V., \& Cochrane, G. (2017).

Page $7 / 10$ 
Velásquez, A. V., Quintero, M., Jiménez, E. Y., Blandón, L. M., \& Gómez, J. (2018). Microorganismos marinos extremófilos con potencial en bioprospección. Revista de la Facultad de Ciencias, 7(2), 9-43. https://doi.org/10.15446/rev.fac.cienc.v7n2.67360

Velmurugan, N., Kalpana, D., Cho, J.-Y., Lee, G.H., Park, S.-H., \& Lee, Y.-S. (2011). Phylogenetic analysis of culturable marine bacteria in sediments from South Korean Yellow Sea. Microbiology, 80(2), 261. https://doi.org/10.1134/S0026261711010188

Vides, M., \& Alonso, D. (2016). Levantamiento de información ambiental de sistemas marinos y costeros sobre el Caribe colombiano (p. 193) [Informe técnico final]. ANH-INVEMAR. http://cinto.invemar.org.co/alfresco/d/d/workspace/SpacesStore/146265f4-56d7-43eb-a433-

7d6cad99cc1c/LEVANTAMIENTO\%20DE\%20INFORMACI\%C3\%93N\%20AMBIENTAL\%20DE\%20SISTEMAS\%20MARINOS\%20Y\%20COSTEROS\%20SOBRE\%20E ticket=TICKET_23ccd90907f4a85a6d990d14c13b6b21079a8269

Vides, M., Santos-Acevedo, M., \& Alonso, D. (2017). Estudio técnico ambiental de línea base en el área de evaluación COL 3 sobre la cuenca sedimentaria del Caribe colombiano. (Convenio 139-17. ANH - INVEMAR, p. 376) [Informe técnico final]. Instituto de Investigaciones Marinas y Costeras INVEMAR. http://cinto.invemar.org.co/alfresco/d/d/workspace/version2Store/440af9ae-a167-449b-a768-b2a8735bd311/PRY_BEM_ANH_13_17_ITF.pdf? ticket=TICKET_23ccd90907f4a85a6d990d14c13b6b21079a8269

Vides, Martha, M., \& Alonso, D. (2018). Estudio técnico ambiental de línea base en el área de evaluación COL 10, extremo norte del Caribe colombiano (Técnico final Convenio 340-18; p. 416). ANH-INVEMAR. http://cinto.invemar.org.co/alfresco/d/d/workspace/version2Store/505a55e9-2ec5-42ab-ac55a8ff1fa561d9/Estudio\%20T\%C3\%A9cnico\%20Ambiental\%20de\%20L\%C3\%ADnea\%20Base\%20en\%20el\%20\%C3\%81rea\%20de\%20Evaluaci\%C3\%B3n\%20Col\% \%20ANH\%20COL10?ticket=TICKET_23ccd90907f4a85a6d990d14c13b6b21079a8269

Vreeland, R. H., Litchfield, C. D., Martin, E. L., \& Elliot, E. Y. 1980. (1980). Halomonas elongata, a New Genus and Species of Extremely Salt-Tolerant Bacteria. International Journal of Systematic and Evolutionary Microbiology, 30(2), 485-495. https://doi.org/10.1099/00207713-30-2-485

Walter, V., Syldatk, C., \& Hausmann, R. (2013). Screening Concepts for the Isolation of Biosurfactant Producing Microorganisms. Landes Bioscience. https://www.ncbi.nlm.nih.gov/books/NBK6189/

Zhang, Z., Wu, Y., \& Zhang, X.-H. (2018). Cultivation of microbes from the deep-sea environments. Deep Sea Research Part II: Topical Studies in Oceanography, 155, 34-43. https://doi.org/10.1016/j.dsr2.2017.07.008

Zinger, L., Amaral-Zettler, L. A., Fuhrman, J. A., Horner-Devine, M. C., Huse, S. M., Welch, D. B. M., Martiny, J. B. H., Sogin, M., Boetius, A., \& Ramette, A. (2011). Global Patterns of Bacterial Beta-Diversity in Seafloor and Seawater Ecosystems. PLOS ONE, 6(9), e24570. https://doi.org/10.1371/journal.pone.0024570

Zobell, C. E., \& Morita, R. Y. (1957). Barophilic bacteria in some deep sea sediments. Journal of Bacteriology, 73(4), 563-

568. https://www.ncbi.nIm.nih.gov/pmc/articles/PMC314618/.

\section{Supplementary}

Figure S2 is not available with this version.

\section{Figures}

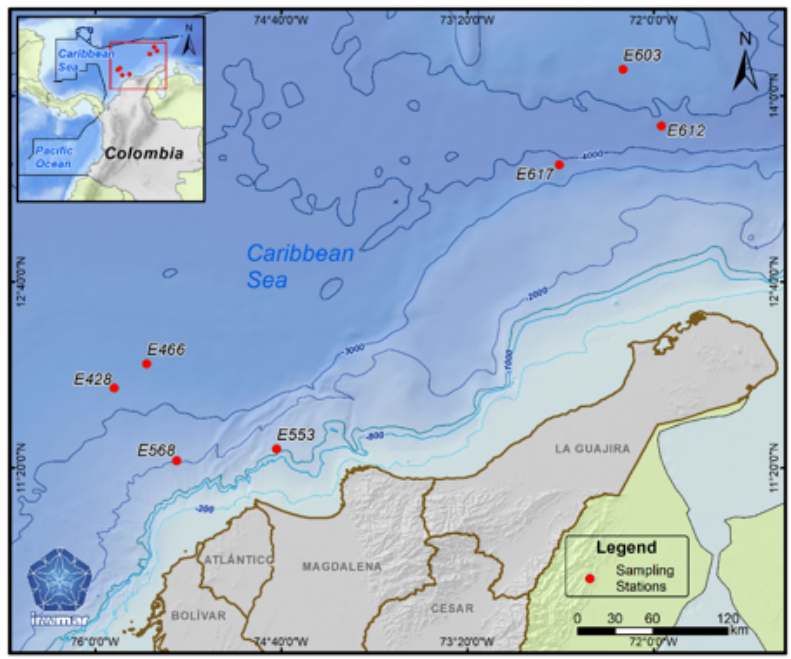

\section{Figure 1}

Sampling stations of collection of marine deep sediments at the Colombian Caribbean Sea 


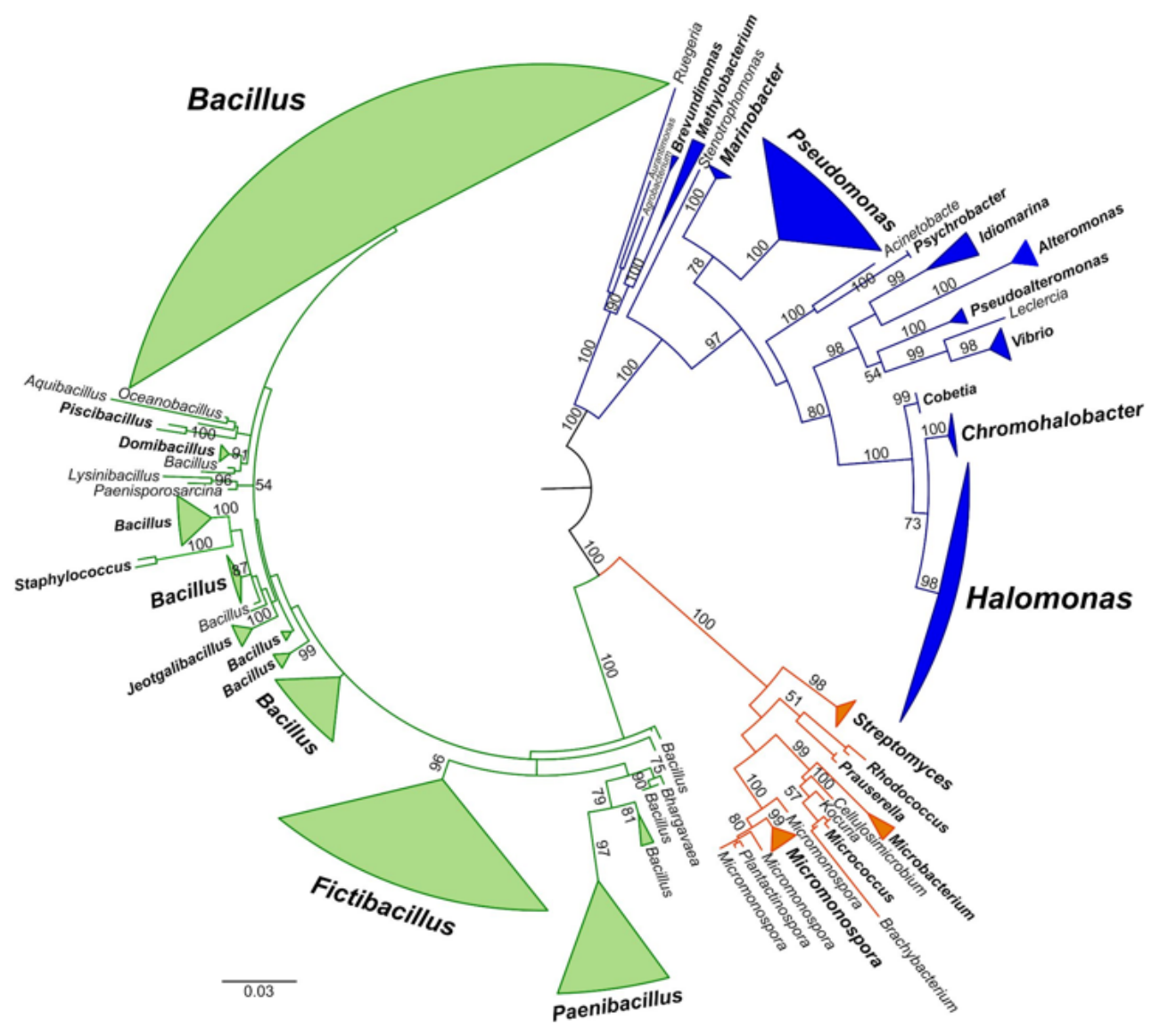

\section{Figure 2}

Maximum likelihood (ML) tree on the GTR + G model (In -14587.3509), based on the nearly complete and aligned 16S rRNA gene sequences. Above the branches, bootstrap support values $(>50)$ are provided for each node. 
A

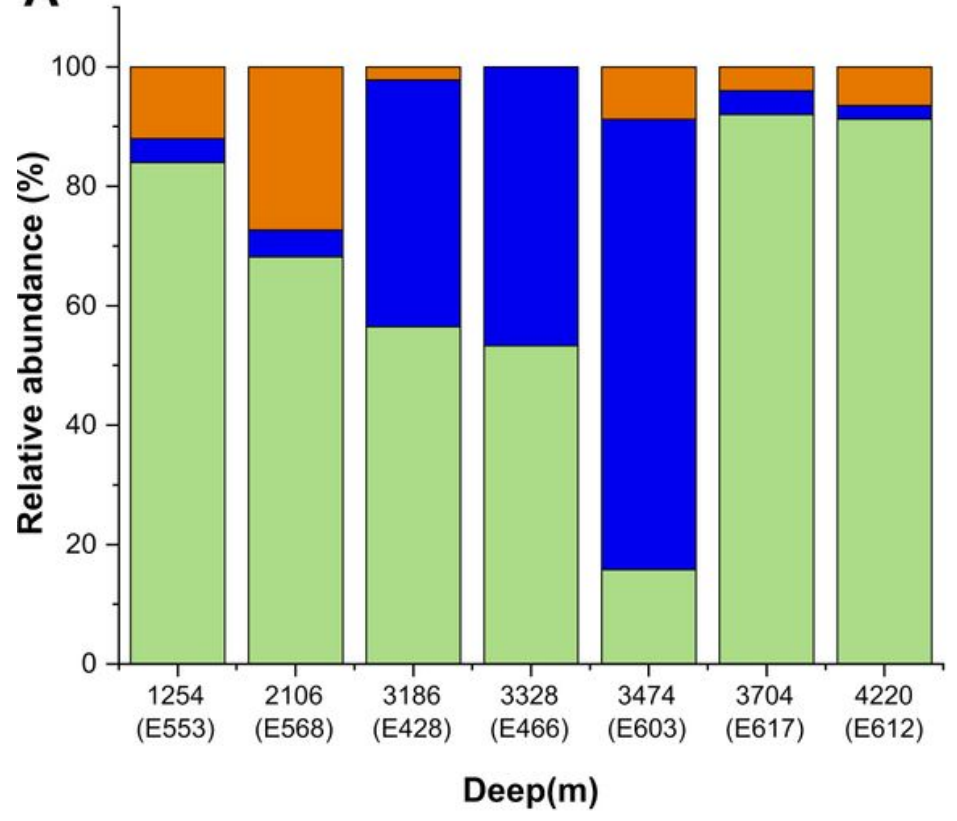

B

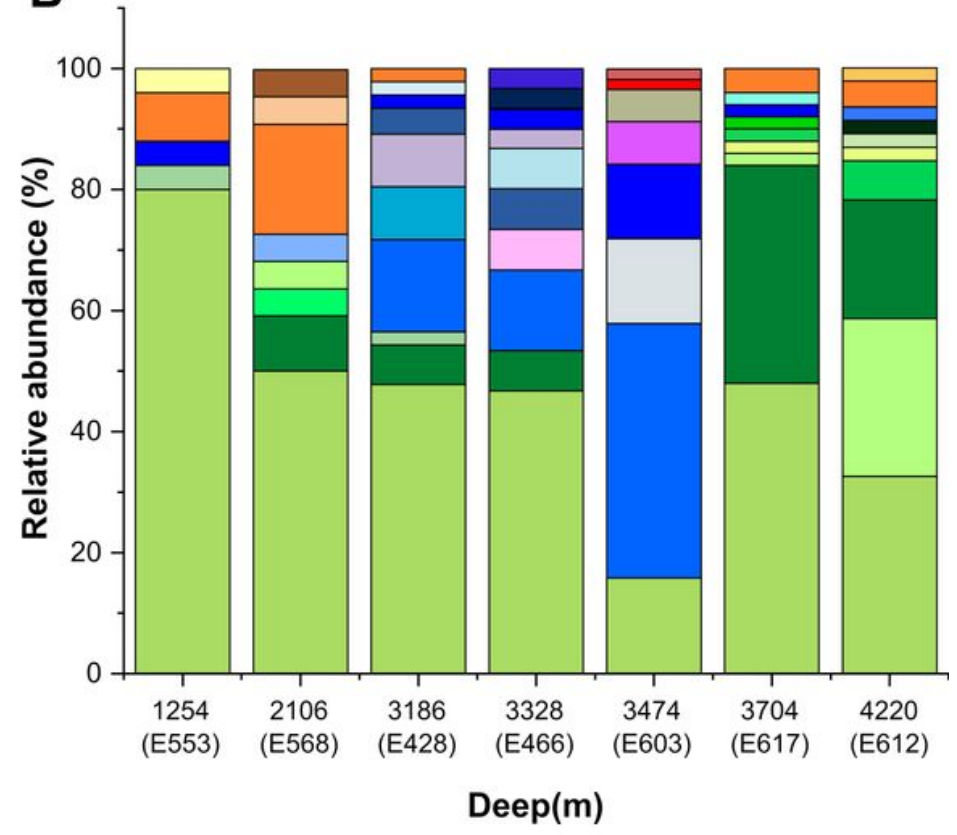

Actinobacteria

Proteobacteria

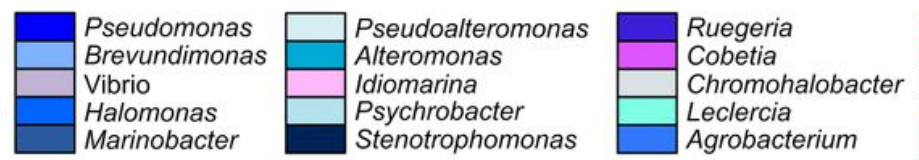

Micromonospora Streptomyces Micrococcus

Cellulosimicrobium

Rhodococcus

Microbacterium

Prauserella

Plantactinospora

Figure 3

Relative abundance of the isolated marine bacteria according to each station and deep. A. Phylum relative abundance. B. Genus relative abundance

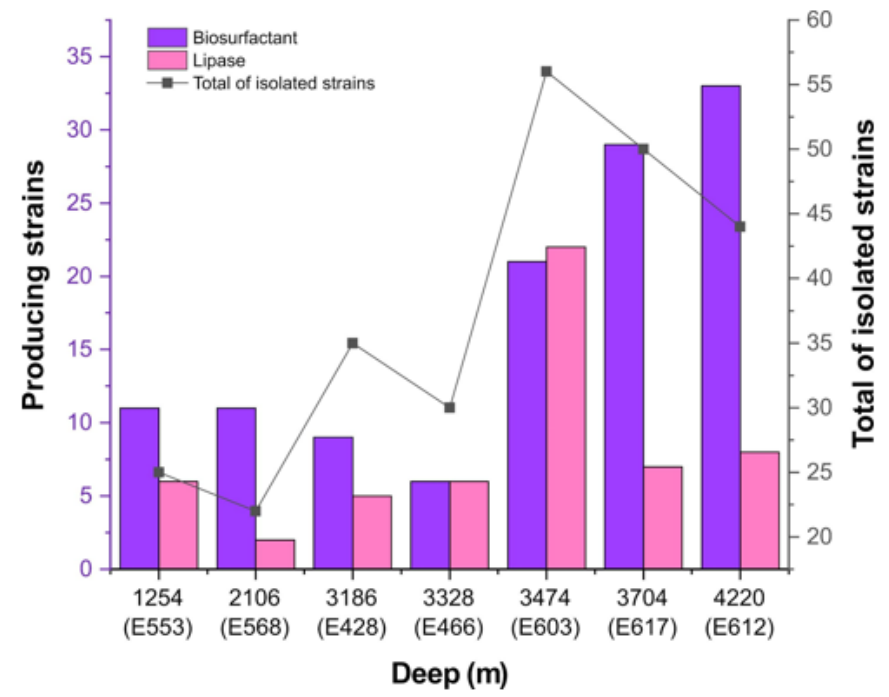

Figure 4

Biosurfactant and lipases producing strains

\section{Supplementary Files}

This is a list of supplementary files associated with this preprint. Click to download.

- Supplementarymaterial.docx 